\title{
The Enlightened Significance of German Retirement Welfare System to Domestic Aging Population
}

\author{
Jingwei $\mathrm{Xu}^{1, *}$, Shikun Gong ${ }^{2}$, Li Shen ${ }^{3}$ \\ ${ }^{l}$ Sino-German College \& The Institute of Public Diplomacy, University of Shanghai for Science and Technology, \\ P.R. China \\ ${ }^{2}$ Nanjing Institute of Tourism and Hospitality, P.R. China \\ ${ }^{3}$ Sino-German College, University of Shanghai for Science and Technology, P.R. China \\ *Corresponding author. Email: jingwei.xu@outlook.com
}

\begin{abstract}
With the progress of modernization and improvement of civil life quality, the average national life expectancy keeps extending. Along with it came forth challenges concerning an aging population. In comparison to developed countries like Germany, the trend of China's growing domestic aging population fits the natural law in regards to the development of population. This article adopts the method of case study and comparative research in respect of the current situation of China's aging population, to analyse the development process of the reform of the retirement system in developed countries, especially Germany, to further explore certain laws in China in search of solution to an aging society, and finally to put forward numerous feasible suggestions for the healthy development of the nutrition system.
\end{abstract}

Keywords: Aging, German, Retirement, Welfare, China.

\section{INTRODUCTION}

On May 21, 2021, Xi Jinping delivered a speech on "Working Together to Build a Global Community of Health for All" at the Global Health Summit. In his speech, he mentioned "we must put people and their lives first." ${ }^{1}$ With the intense increase of a population aging, the topic of health for all has become one of the hot topics discussed in academia and healthcare industry. From the data released by the National Bureau of Statistics on May 11, 2021, we can see that between 2021 and 2030, the total population and proportion of the working-age population will continue to decline at a relatively rapid rate, and the population dependency ratio will continue to increase, from low. The demographic dividend brought by the population dependency ratio is gradually coming to an end. As the "post-60s"-born in the second baby boom enter the retirement stage, the growth rate of the elderly population will accelerate significantly. By 2030, the proportion of the elderly population will reach $1 / 4$ of

\footnotetext{
${ }^{1}$ CCTV-1 Comprehensive Channel. Xi Jinping attended the Gl obal Health Summit and delivered an important speech. CCTV Network, 2021-5-21.https://tv.cctv.com/2021/05/21/VIDES23 1lihSmknk8PKxPdDc210521.shtml.
}

the total population. The numbers and the increase are more obvious.

During the "14th Five-Year Plan" period, China will transform from a "lightly aging" country to a "moderately aging" country. In 2020, the total number of elderly people aged 60 and over in the mainland area is 264 million, accounting for $18.7 \%$ of the total population. From the "sixth population census" in 2010 to the seventh national population census in 2020 , the increase was by a percentage 5.4 points higher. In the 20 years since entering an aging society in 2000 , the proportion of the elderly population has increased by $8.4 \%{ }^{2}$ The proportion of the elderly population from 2011 to 2020 is significantly higher than that of the previous 10 years, mainly due to the first birth peak in the 1950s. The population cohort formed has entered the old age one after another.

In this context, experts and scholars from both political and academic circles who study social development are thinking about such questions: How should China's retirement system reform and develop?

\footnotetext{
${ }^{2}$ Z. Zhai, Population opportunities and challenges for highquality development in the new era, Economic Daily, 2021-512. https://proapi.jingjiribao.cn/detail.html?id=339961
} 
What lessons can we learn from the retirement reforms in other countries? These questions are the keys to this article.

\section{LITERATURE REVIEW}

As early as 2005, Du Peng and others predicted the development trend of population aging in China in a 100year cycle, and the results showed that China will quickly enter a period of rapid population aging from 2021 on; between 2010 and 2032 , the proportion of the elderly population (over 60 years old) will increase by about $0.5 \%$ every year, reaching $31 \%$ by the middle of this century, and will continue to increase to about $34 \%$ by the end of this century; the peak of the number of elderly people (over 60 years old) in China will appear in 2053, it is estimated to be close to 430 million; by 2100 , the number of elderly people will gradually drop to 350 million. ${ }^{3}$ In 2006, Li Bengong also published "A Century-old Forecast of the Development Trend of Population Aging in China". ${ }^{4}$ In the report, he also mentioned the changes in the regional trends of population aging. By the 1940s, the phenomenon of urban population aging will become particularly serious. What is outstanding is that China's total elderly population will exceed 400 million by 2050 , and the aging level will also advance to more than $30 \%$.

On May 11, 2021, the National Bureau of Statistics of China announced the results of the seventh population census of 141178 million. Between 2021 and 2030, the total and proportion of the working-age population will continue to decline at a relatively rapid rate, the population dependency ratio will continue to increase, and the population dividend brought by the low population dependency ratio will gradually come to an end. During the "14th Five-Year Plan" period, China will move from a mild aging to a moderate aging pace. As the "post-60s" born in the second baby boom enter the retirement age, the growth rate of the elderly population will accelerate significantly, and the proportion will reach about $25 \%$ by 2030 , of which the population of elderly people aged 80 and above will increase more significantly. ${ }^{5}$ In 2020 , the total number of elderly people 60 years old and above in the mainland area will be 264 million, accounting for $18.7 \%$ of the total population. In the 20 years since entering an aging society in 2000 , the proportion of the elderly population has increased by $8.4 \%,{ }^{6}$ among which, from the "six-population" in 2010

\footnotetext{
${ }^{3}$ P. Du, Z. Zhai, W. Chen, The development trend of China's population aging over a century. Population Research, Vol. 29, 2005, pp.90-93.

${ }^{4}$ B. Li, A Century-old Forecast of the Development Trend of Population Aging in China, Beijing: Hualing Publishing House, 2006.
}

${ }^{5}$ People's Daily Online. my country's population development to the seventh national population census in 2020, it has increased by $5.4 \%$ in the 10 years. , The latter 10 years obviously surpassed the previous 10 years, which is mainly related to the population cohort formed by the first birth peak in the 1950 s, which has entered into old age.

The phenomenon of population aging in developed countries appeared relatively early. Currently, the top three aging populations in the world are Japan, Italy and Germany. These countries have begun to explore solutions to the aging of their populations very early. Take Germany as an example. At the government and social levels, Germany has adopted different forms including medical insurance classification, revision and improvement of labor regulations, and various other supplementary forms to support retirement work. The government level mainly adopts the form of financial subsidies and universal medical insurance, and treats basic diseases and special situations according to classification, and adopts the "three-in-one" model to promote.

In the traditional sense, the embryonic form of the pension system in Germany stems from the internal support of the family. In the whole of Europe, Germany's industrialization started relatively late. A large family in the main labor class must be responsible for the daily expenses and care of the whole family, among which the two important aspects are pension and child care. Only a few widows need special assistance from the state or society, and this assistance are usually only the most basic aspects of life. Since the $17^{\text {th }}$ Century, with the development of industrialization, social security, including old-age security, has gradually come into people's vision. With the establishment of the German Empire in the $19^{\text {th }}$ Century, the legislation of the pension system has become possible under the framework of Prime Minister Bismarck's government. The government of the pension system gradually approached the old habits of the family for the elderly. But the two world wars and the financial crisis in the first half of the twentieth Century also brought Germany to its previous efforts in the construction of the pension system. Until $1950 \mathrm{~s}$, the government put the problem of retirement on the table again. In the past 150 years, the government has summed up some experience in family and individual pension, which has become a "Trinity" model for the state to formulate policies and leading, the specific

presents new characteristics and new trends-Interpretation of the Seventh National Census Communiqué, 2021-5-13, http://www.stats.gov.cn/tjsj/sjjd/202105/t20210513_1817394.h tml.

${ }^{6}$ Z. Zhai. Population opportunities and challenges for highquality development in the new era. 2021-5-12, https://proapi.jingjiribao.cn/detail.html?id=339961. 
implementation and operation of collective units and the supplement of individual personality for the aged.

The "Trinity" mode is mainly embodied in the following three levels: First, the legal system level: Through the retirement insurance system, the basic social insurance of the employment units, the agricultural pension insurance (Adl), the special technical industry subsidy (BSV), the art employment insurance and the public service insurance are made up. Second, supplementary labor endowment insurance: The insurance cost is mainly paid by the enterprise. In some special cases, the Public Affairs Bureau (ZÖD) pays extra fees. Third, personal pension fund: It can be obtained

Table 1. Relation table of retirement age and tax rate through various regulations for the retired personnel, mainly including the fund savings plan, the tax exemption or tax reduction rules for retirees, and the ownership of real estate. Another German three - layer division of retirement is often criticized since 2000 , mainly through the tax regulation of the state, enterprises and individuals to calculate the funding for the pension phase. This calculation method is too complicated and has many loopholes. Now it is only a supplementary way of subsidizing. Due to different occupations, retirement age also varies. This difference leads to a difference in individual tax rates after retirement. Generally speaking, there are several correlations. They are based on the actuarial calculation of life table (or mortality table).

\begin{tabular}{|c|c|c|c|c|c|c|}
\hline retirement age $($ years old $)$ & $\mathbf{6 0}$ & $\mathbf{6 1}$ & $\mathbf{6 2}$ & $\mathbf{6 3}$ & $\mathbf{6 4}$ & $\mathbf{6 5}$ \\
\hline tax rate $(\%)$ & 22 & 22 & 21 & 20 & 19 & 18 \\
\hline
\end{tabular}

While perfecting and correcting the social insurance payment and the government subsidy system, Germany also has a clear regulation for the special group's retirement support. Because of the differences in cultural traditions and social systems, many women in Germany will give up their work after marriage or childbirth, focusing on family affairs, including raising children and so on. This naturally leads to the emergence of a pension gap, known as the "Gender Pension Gap". By analysing some data from the organization for economic cooperation and development (OECD), it has been found that the gender pension gap in Germany reached $44 \%$ in 2011, two times the average of the data OECD gave the same year $(28 \%)^{7}$. The 2014 data analysis points to another problem: the gender pension gap in the new and old federal states is very uneven, at $23 \%$ in the new federal state and $42 \%{ }^{8}$ in the traditional federal state.

The German government has considered the family subsidy factor in the retirement system. As those engaged in family work also undertake corresponding social work and responsibility, especially in the period of retirement, these women will calculate a lower level of income subsidies, so the German government has also made other special provisions in the system of retirement, including for divorced women, which can obtain a large return insurance income from the former husband. The new rights act of 2008 amended it, most of which was borne by the government, which also relieved the burden of men who had already paid more in the regular profession. However, many family women are too trusting and dependent on their families, and individuals do not make

\footnotetext{
${ }^{7}$ Bundesministerium für Familie, Gender Pension Gap, Senioren, Frauen und Jugend, 2011.
}

${ }^{8}$ DIW Wochenbericht 5/2017, Gender Pension Gap. supplementary insurance, which leads to life embarrassment in their old age. In order to solve these problems, the German Federal Parliament passed a "compensatory maintenance" by a majority of votes in December 13, 2012 and refined the specific amount of government subsidies with the actual time of marriage maintenance. ${ }^{9}$ Such a security system takes into account the relationship between the demographic dividend and socio-economic development. By encouraging women to invest time in the family, they can increase their energy release in childbearing, parenting and children's education, objectively having a certain inhibitory effect on the aging of the German population.

Indeed, in addition to the traditional retirement system and payment rules, people can also make some additions through some ways. For example, the insurance of occupational disability or non-working ability, serious illness, serious illness special allowance, accident insurance, widowed pension and orphan subsidy. These special expenses are generally incurred by the government. Of course, some charities and foundations have also helped a lot. In a word, the German retreat system has been revised for a long time, and gradually formed a system model suitable for the actual situation of the country, which has certain reference significance.

\section{INSPIRATION FROM "GERMAN MODEL"}

We could get some inspiration from "German model" to solve the problem of aging population in China. Since

\footnotetext{
${ }^{9}$ Beschlussempfehlung und Bericht des Rechtsausschusses: zu dem Gesetzentwurf der Bundesregierung, Ergänzung des \$ 1578b BGB vom 13. Dezember 2012.
} 
the founding of the People's Republic of China, the socialist social welfare system has undergone some twists and turns, and has gone through some detours. However, with the continuous improvement of the political and economic status of the country and the enhancement of comprehensive national strength, the rehabilitation system is also improving. The system covers five levels of social security network in provinces, cities, counties, townships and villages, and it will also form a special pattern in different regions. In general, we should form think tanks in the classification management of capital investment and pension mode, network and artificial intelligence, and special crowd protection, and also pay attention to the law of sustainable development under the development of population aging.

\subsection{Capital investment and pension}

We should classify and manage the mode of capital investment and pension. In the traditional sense, the capital investment is generally allocated by the government, and after the extensive statistics is used, the actual use efficiency is not satisfactory. Nowadays, the imbalance of regional economic development requires us to think more about places. For the provinces and regions with relatively weak infrastructure, the traditional mode of government investment can be mainly adopted. For the relatively developed areas, the individualized demand should be taken into account; both the public investment of the government and the investment of the private capital should be attracted. On the other hand, through the analysis of tax rate regulation and actual working years and contribution rate, we can reduce the economic pressure of the retired personnel. At the same time, we should gradually promote the new mode of the old age for the community, family and individual, such as the way of housing for the aged, and encourage the elderly to migrate to the three or four line city. On the one hand, it can reduce the cost of the retirement, on the other hand, it can relieve the foundation of the first-tier cities.

\subsection{Use of the advantages of networking and artificial intelligence}

We should make full use of the advantages of networking and artificial intelligence to explore new ways to retreat. For nearly ten years, Chinese in "Internet plus", artificial intelligence (AI), the rapid development of network etc. The use of network technology can provide services for the retired people remotely, and also provide a new possibility for their children; the further promotion of AI technology can provide the convenience for the disabled, and can objectively share the content of the spirit of the elderly to their children. "Internet plus" to promote the experience, you can solve the problem of a part of the elderly diet distribution, conduct basic medical and physical examination, engage them in reading and entertainment activities.

\subsection{Concern for special groups}

In recent years, the "second child"- or "third child" policy has solved some of the lack of potential labor force on the one hand, but it has also led to the early termination of many young women's careers. Apart from that, reports show that young white-collars met their sudden deaths due to overload of work in recent years. Some people who have just retired are unable to take care of themselves at that stage because of their mental and physical overload. These special groups should also be paid attention to, and the state and local areas can further improve and refine such security provisions at the legislative level; meanwhile, the government should also appropriately liberate the private pension and security scope, appropriately reduce the access threshold of the foreign capital withdrawal institutions, and provide certain policy guarantees for some non-profit raising institutions. This will also reduce the burden of the government's pension and alleviate the pressure brought by the aging problem.

\section{CONCLUSION}

Through research on the development of the retirement system in developed countries, especially in Germany, China can further think in many aspects such as capital investment and hierarchical management of pension models, exploring new retirement methods, and paying attention to special groups. Pay special attention to research on the dynamic issues of population aging development. We should pay attention to the trend of aging population: the aging population of cities and towns, the proportion of aging population in rural areas, the proportion of aging population in the central, western and coastal areas, the demands and standards of the retirement services in the developed and underdeveloped areas, the sex ratio of the birth population and the deceased population...In a word, through the cross disciplinary research of statistics, environmental science, economics and sociology, we firmly grasp the law of sustainable development under the development of population aging. At the same time, we can improve the people's livelihood and enhance the sense of the people, especially the people, while completing the "two goals of the one hundred year struggle".

\section{REFERENCES}

[1] B. Ebbinghaus, Multipillarisation remodelled: the role of interest organizations in British and German pension reforms, Journal of European Public Policy, Vol. 26, 2019, pp. 521-539. DOI: $10.1080 / 13501763.2019 .1574875$

[2] M. Haverland, S. Stiller, The Grand Coalition and P ension and Health Care Reform, German Politics, V ol. 19, 2010, pp. 429-445. DOI: 10.1080/09644008. 2010.515831 
[3] T. L. Hungerford, The economic consequences of widowhood on elderly women in the United States and Germany, Gerontologist, Vol. 41, 2001, pp. 103-110. DOI: 10.1080/09644008.2010.515831

[4] E. Kauth-Kokshoorn, Wohn- und Lebenssituation alterer auslandischer Hamburgerinnen und Hamburger, Bundesverband der Arzte des Offentlichen Gesundheitsdienstes, German, Vol. 61, 1999, S.522-527.

[5] M. Kohli, Retirement and the moral economy: An historical interpretation of the German case, Journal of aging studies, Vol. 1, 1987, pp.125-144. DOI: 10.1016/0890-4065(87)90003-X

[6] M. Kohli, H. Kunemund, J. Wolf, Trade unions and the elderly population: Is retirement still linked to the sphere of work? Scandinavian Journal of Social Welfare, Vol. 6, pp.180-188. DOI: 10.1111/j.14682397.1997.tb00187.x

[7] C. Torp, The Adenauer Government's Pensions Reform of 1957-a Question of Justice, in: German History, Vol. 34, 2016, pp.237-257. DOI: 10.1093/gerhis/ghw001

[8] T. Boeri, A. Boersch-Supan, G. Tabellini, Pension r eforms and the opinions of European citizens, Ame rican Economic Review, Vol. 92, 2002, pp. 396-40 1. DOI: $10.1257 / 000282802320191688$

[9] E. Kibele, R. Scholz, V. M. Shkolnikov, Low Migrant Mortality in Germany for Men Aged 65 and Older: Fact or Artefact? European Journal of Epidemiology, Vol. 23, No. 6 (2008), pp. 389-393. DOI: $10.1007 / \mathrm{s} 10654-008-9247-1$

[10] N. Stawarz, N. Sander, H. Sulak, M. Rosenbaum-F eldbrügg. The turnaround in internal migration bet ween East and West Germany over the period 1991 to 2018, Max Planck Inst Demographic, Vol. 43, 2 020, pp. 993-1008. DOI: 10.4054/DemRes.2020.43 .33

[11] T. Boeri, A. Borsch-Supan, G. Tabellini, KO. Moene, B. Lockwood, Would you like to shrink the welfare state? A survey of European citizens, Economic Policy, Vol. 32, 2001, pp.7-50.

[12] A. Seibold, Reference Points for Retirement Behavior: Evidence from German Pension Discontinuities, American Economic Review, Vol. 111, 2021, pp. 1126-1165. DOI: 10.1257/aer.20191136 